DEPARTMENT OF ECONOMICS WORKING PAPER SERIES

Endogenous Money in the Age of Financial Liberalization

Gökçer Özgür

Korkut A. Ertürk

Working Paper No: 2008-06

\author{
University of Utah \\ Department of Economics \\ 1645 East Central Campus Dr., Rm. 308 \\ Salt Lake City, UT 84112-9300 \\ Tel: (801) 581-7481 \\ Fax: (801) 585-5649 \\ http://www.econ.utah.edu
}




\title{
Endogenous Money in the Age of Financial Liberalization
}

\author{
Gökçer Özgür \\ Hacettepe University, Department of Economics \\ Korkut A. Ertürk* \\ University of Utah, Department of Economics
}

\begin{abstract}
The paper reports results that show a much weakened statistical relationship between total bank credit, total deposits and the broad money supply for the period after 1995 for the US, where no statistical causation can be discerned in either direction. This has been the result of the changing nature of the credit creation process where banks have acquired almost total independence from required reserves and core deposits in extending credit, and even an ability to circumvent the constraint posed by capital requirements through asset securitization, giving rise to an explosive increase in nonbank intermediation. As a result, the expansion of bank credit did not result in a commensurate increase of bank deposits because financial intermediation spilled over to nondepository institutions, and with the growing importance of nonbank deposits in M3, broad money supply became broader than banks' total deposits.
\end{abstract}

JEL Code: B22, E12, E51

Keywords: Endogenous Supply of Money, Broad Money, Financial Intermediation, Asset Securitization

*Corresponding author. 


\section{Introduction}

The role depository institutions play in the credit creation process has undergone significant changes since the early 1980s. As financial deregulation gave rise to increased competition from nondepository financial institutions, commercial banks lost many of their advantages in attracting savings and were forced to innovate, transforming the role banking played in money and credit creation mechanisms along the way. Not only commercial and industrial loans have decreased in importance in the overall credit supply in the economy, but their relative importance in banks' total assets has experienced a steady decline as well. Traditional banking today as a result is no longer as central to credit creation as it once was before the era of financial liberalization. But, despite the explosive increase in non-bank lending, it has hardly been a major topic of concern within the endogenous money literature. A debate that had its origin on the issue of how banks met their reserve requirements when they extended credit has instead remained the center of attention throughout much of the 1990s and even beyond (Pollin, 1991; Fontana, 2003; Lavoie, 2007; Dow, 2007). In much of these discussions, it is as though traditional banking is still the backbone of the credit system. But, clearly, it no longer is and that has important ramifications for the money creation process. The main motivation of this paper is to address this gap by revisiting the empirical relationship between bank credit and broad money.

Much of the empirical work on endogenous money has traditionally involved the estimation of two separate relations between: (i) the borrowing needs of nonfinancial businesses and bank credit; and, (ii) overall bank credit, deposits and the broad monetary aggregates (Howells, 2007). In relation to the first relation, the basic idea was to show that bank credit demand was driven by the production decisions of firms, and early formulations focused on the relationship between bank loans and the working capital needs of private businesses (Moore $\&$ Threadgold, 1985; Moore, 1988). As firms' financing needs for working capital lost much of its explanatory power in later years (Hewitson, 1997), research began to shift to a broader-based demand for bank credit, reflecting the growing importance of non-GDP transactions and household sector's credit needs (Arestis and Mariscal, 1995; Howells and Hussein 1999). ${ }^{1}$

In relation to the second relation, the argument that a unidirectional line of causation ran from bank loans to monetary aggregates was first supported by means of Granger and Sims causality tests (Moore, 1988; Palley, 1994), and later by estimating a vector error correction model in which the lagged cointegrating residuals were included as an explanatory variable before being tested for Granger causality (Howells and Hussein; 1998). The results in this latter study were broadly positive across the G7 countries, showing that bank loans Granger-cause broad money, though some evidence of reverse causality (running from deposits to loans) was also reported, more so for some countries than others.

In this paper, we report results that show a much weakened statistical relationship between total bank credit, total deposits and the broad money supply for the period after 1995 for the US, where no statistical causation can be discerned in either direction. We leave the first relation between credit demand and bank loans, probably much weaker in this period as well (Caporale and Howells, 2001), outside the scope of this paper and focus solely on the loandeposit-money link, showing that it has acquired a much more complex character after the mid 1990s because of the transformations that have taken place in the credit system since.

The paper is organized into three sections. We give a brief descriptive overview of the declining role of traditional banking in the credit creation process in Section II, and present 
statistical evidence showing that the relationship between total bank credit and the broad money supply has become tenuous, if not nonexistent, after the mid 1990s in Section III. We discuss what might be the main determinants of this finding in Section IV, and end with a few concluding remarks about its broader significance.

\section{Decline of Traditional Banking}

Short term bank loans' share in overall borrowing in the US economy shows a clear procyclical pattern before 1980, i.e., rising during economic booms and declining either during or immediately after recessions. ${ }^{2}$ However, their share begin to fall steadily since the early 1980 s, as short term bank loans gradually get replaced with both nonbank short-term and long-term (bank and nonbank) borrowing. The decomposition in the identity equation (1) gives an overview of this transformation.

$$
\begin{aligned}
\ln (\text { stbank } / \mathrm{cmi}) & =\ln (\text { stbank } / \text { stnonbank })+\ln (\text { stnonbank } / \text { ltbank }) \\
& +\ln (\text { ltbank } / \text { tnonbank })+\ln (\text { ltnonbank } / \mathrm{cmi}),
\end{aligned}
$$

where stbank is short-term borrowing from commercial banks (bank loans n.e.c.), cmi is credit market instruments (total borrowing), stnonbank is short-term borrowing from nonbank sources (commercial paper and other loans from nonbank financial institutions), ltbank is long-term borrowing from commercial banks (mortgage loans), and ltnonbank is long-term borrowing nonbank sources (corporate and municipal bonds); all data is quarterly and from L.102 Table of Flow of Funds Accounts of the Federal Reserve.

A few observations help summarize the main results reported in Table 1 below, the growth rate of each ratio in (1) and their (exponential) estimates for different business cycle periods. $^{3}$

(i) The ratio of bank lending to total borrowing, stbank/cmi, shows a decrease of 1.06 percent in its average growth rate over the full period. It rises steadily until the fourth business cycle in our sample and mainly falls since then. During the short-lived expansion between sixth and the seventh business cycle a small increase is discernable, but the declining trend becomes dominant during the 1990 s and 2000s.

(ii) As expected, the ratio of short term bank to nonbank, stbank/stnonbank, ratio shows a large negative growth rate over the full period.

(iii) Likewise, the ratio of long-term bank borrowing to long-term nonbank borrowing, ltbank/ltnonbank, shows a similar pattern. Even though this latter trend is partially reversed after 2000, because of the fast growth of mortgage loans, the share of long-term nonbank borrowing in total borrowing still increases for both the overall sample and for the period of last 15 years. 
Table 1. Growth Rates, (\%)

\begin{tabular}{llllllllll}
\hline & $1953: 2-$ & $1957: 3-$ & $1960: 2-$ & $1969: 4-$ & $1973: 4-$ & $1980: 1-$ & $1981: 3-$ & $1990: 3-$ & $2001: 1-$ \\
& $1957: 2$ & $1960: 1$ & $1969: 3$ & $1973: 3$ & $1979: 4$ & $1981: 2$ & $1990: 2$ & $2000: 4$ & $2005: 2$ \\
Cycles & $\mathbf{1}$ & $\mathbf{2}$ & $\mathbf{3}$ & $\mathbf{4}$ & $\mathbf{5}$ & $\mathbf{6}$ & $\mathbf{7}$ & $\mathbf{8}$ & $\mathbf{9}$ \\
\hline
\end{tabular}

Growth Rates

\begin{tabular}{l|lllllllll}
\hline & Full & & & & & & & & \\
& Period & $1-2$ & $2-3$ & $3-4$ & $4-5$ & $5-6$ & $6-7$ & $7-8$ & $8-9$ \\
\hline stbank/cmi & -1.06 & 0.04 & 1.17 & 0.62 & -2.78 & -0.39 & 0.74 & -2.43 & -5.47 \\
Stbank/stnonbank & -4.23 & -1.95 & -4.17 & -2.24 & -7.90 & -8.55 & -2.83 & -3.29 & -2.58 \\
stnonbank/ltbank & 4.68 & 2.73 & 5.02 & 2.08 & 2.74 & 14.24 & 8.29 & 4.29 & -6.14 \\
ltbank/ltnonbank & -1.56 & -0.74 & 1.72 & 1.86 & 2.88 & -6.20 & -4.19 & -4.94 & 1.22 \\
ltnonbank/cmi & 0.05 & 0.018 & -1.39 & -1.07 & -0.50 & 0.11 & -0.52 & 1.50 & 2.01 \\
\hline
\end{tabular}

Source: Estimated from Table L.102, Flow of Funds Accounts

A clear trend is discernable in these results: Short term bank loans' relative magnitude in relation to other types of borrowing has steadily fallen, which implies that nofinancial nonfarm corporations appear to have increasingly utilized a variety of debt instruments other than commercial and industrial loans to meet their demand for external funds. A similar picture emerges when we look at the depository institutions' relative size in the financial sector (Table 2 ), which has been declining steadily since the 1970s, and the growing share of noninterest income $^{4}$ (Figure 1), well in excess of fifty percent by now, in their total gross income. 
Table 2. Percent Share of Assets by Financial Sector ${ }^{A}$, (\%)

\begin{tabular}{lllllllll}
\hline & 1960 & 1970 & 1980 & 1985 & 1990 & 1995 & 2000 & $2005: 2$ \\
\hline Depository Institutions $^{1}$ & 54.65 & 54.41 & 51.96 & 44.18 & 36.08 & 27.78 & 22.83 & 24.22 \\
Insurance Companies $^{2}$ & 22.38 & 17.38 & 14.34 & 12.77 & 13.94 & 13.39 & 11.23 & 11.64 \\
Private Pensions $^{3}$ & 6.44 & 8.56 & 11.38 & 14.30 & 12.03 & 13.79 & 12.23 & 9.38 \\
Public Pensions $^{3}$ & 5.32 & 6.07 & 6.06 & 6.69 & 7.92 & 8.92 & 8.68 & 7.62 \\
Mutual Funds $^{4}$ & 3.68 & 3.66 & 3.24 & 5.79 & 8.54 & 13.04 & 17.95 & 16.42 \\
GSEs \& Agency- and & & & & & & & & \\
GSE-backed Mortgage & & & & & & & & \\
Pools & 1.86 & 3.55 & 6.86 & 8.07 & 11.08 & 11.79 & 12.52 & 13.59 \\
Nonbank Lenders & 4.58 & 4.89 & 4.73 & 4.24 & 4.41 & 3.37 & 3.29 & 3.12 \\
Security Brokers\&Dealers & 1.05 & 1.12 & 1.01 & 1.82 & 1.94 & 2.71 & 3.43 & 4.37 \\
Others $^{6}$ & 0.03 & 0.37 & 0.43 & 2.13 & 4.05 & 5.21 & 7.84 & 9.63 \\
\hline
\end{tabular}

${ }^{\mathrm{A}}$ All numbers are year-end results except 2005 which is $2^{\text {nd }}$ quarter.

${ }^{1}$ Includes commercial banks, saving institutions, and credit unions.

${ }^{2}$ Includes life insurance companies and other insurance companies.

${ }^{3}$ Includes state and local government employee retirement funds, and federal government retirement funds.

${ }^{4}$ Includes money market mutual funds, mutual funds, and closed-end and exchange-traded funds.

${ }^{5}$ Includes finance companies and mortgage companies.

${ }^{6}$ Includes asset-backed securities issuers, real estate investment trusts and funding corporations.

Source: Estimated from Tables L.109 through L.131 of Flow of Funds Accounts. 
Figure 1. Noninterest Income to Gross Income Ratio of Commercial Banks

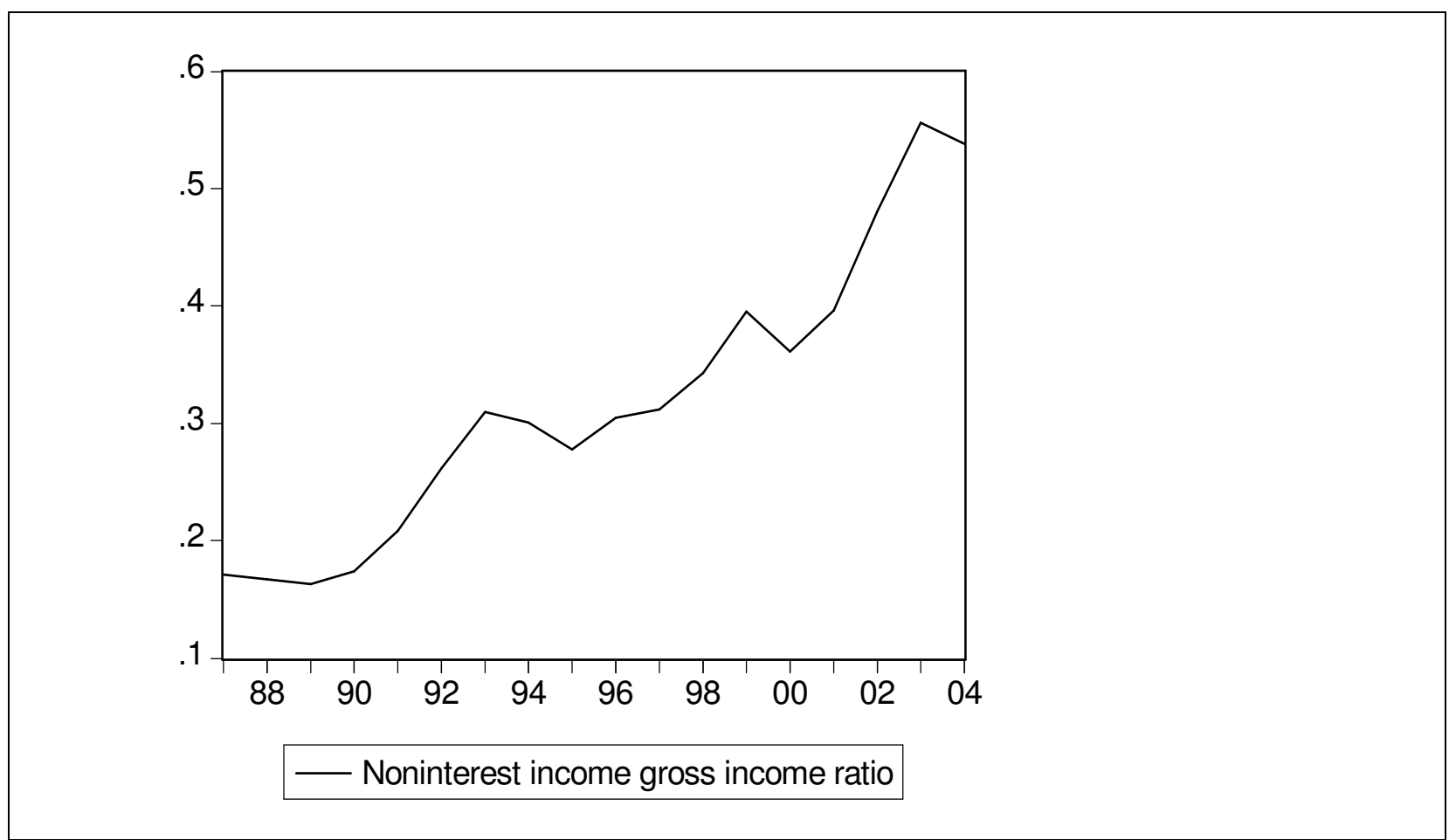

Source: Estimated from the data appendices of Federal Reserve Bulletins, years 1996 through 2004.

It is well known that since the early 1980s commercial banks began to shift their activities to relatively riskier areas in an attempt to maintain profitability. Real estate loans, off-balance sheet activities, and lending for corporate takeovers and leveraged buyouts have all increased in importance as a result. Back up lines of credit and guarantees gained at the expense of actual lending (Boyd and Gertler, 1995) and credit derivatives came to constitute a major share of banks' off-balance sheet activities. ${ }^{5}$ Rising share of loan loss provisions and the growing importance of noninterest income - especially, for the largest 10 banks - were telltale signs of these changes (Edwards and Mishkin, 1995; 33-34). Moreover, just as off-balance sheet activities soared the bank loans' share in total assets in commercial banks' balance sheet declined, replaced increasingly by agency and GSE-backed securities, corporate and foreign bonds and mortgages (Table 3). ${ }^{6}$ 
Table 3. Percent Share of Selected

Assets in Bank Credit, (\%)

\begin{tabular}{lllllllll} 
& $\begin{array}{l}\text { Treasury } \\
\text { securities }\end{array}$ & $\begin{array}{l}\text { Agency- and } \\
\text { GSE-backed } \\
\text { securities }\end{array}$ & $\begin{array}{l}\text { Municipal } \\
\text { securities }\end{array}$ & $\begin{array}{l}\text { Corporate } \\
\text { and foreign } \\
\text { bonds }\end{array}$ & $\begin{array}{l}\text { Open } \\
\text { market } \\
\text { paper }\end{array}$ & $\begin{array}{l}\text { Bank } \\
\text { loans } \\
\text { n.e.c. }\end{array}$ & Mortgages & $\begin{array}{l}\text { Consumer } \\
\text { credit }\end{array}$ \\
\hline 1952 & 45.85 & 1.23 & 7.11 & 1.87 & 0.41 & 23.11 & 11.02 & 7.57 \\
1960 & 29.11 & 0.85 & 9.07 & 0.80 & 0.43 & 29.36 & 15.01 & 13.00 \\
1970 & 12.52 & 2.51 & 14.52 & 0.44 & 0.87 & 34.75 & 17.04 & 15.02 \\
1980 & 8.19 & 4.55 & 11.60 & 0.83 & 1.07 & 35.50 & 21.21 & 15.61 \\
1985 & 10.81 & 4.41 & 9.53 & 1.30 & 0.51 & 34.80 & 21.90 & 15.01 \\
1990 & 6.71 & 9.43 & 4.88 & 3.22 & 0.36 & 30.09 & 29.71 & 13.98 \\
1995 & 9.07 & 12.78 & 2.81 & 2.97 & 0.13 & 25.54 & 30.45 & 13.54 \\
2000 & 4.47 & 14.68 & 2.29 & 4.16 & 0.03 & 28.86 & 31.66 & 10.40 \\
2005 & 1.80 & 16.01 & 2.08 & 8.98 & 0.00 & 19.25 & 38.42 & 9.86 \\
\hline
\end{tabular}

Source: Estimated from Table L.109, Flow of Funds Accounts.

\section{Link Between Bank Credit, Deposits and Broad Money}

In what is to follow, we concentrate on broad money as do all later studies. As well known, financial innovations and deregulation has made it increasingly difficult to define narrow money and thus to delineate it from the measures of broad money supply. ${ }^{7}$ Though problems also exist with the definition of broad money, these did not seem as formidable - at least not until very recently. ${ }^{8}$ Of course, focusing on broad money had also the advantage of sidestepping the need to estimate portfolio decisions of both the depository institutions and the borrowers.

We present two sets of empirical evidence to show that the statistical link between total bank credit and broad money has become tenuous at best after the mid-1990s. First are the results of our effort to replicate Howells and Hussein (1998) for the US who show that overall bank credit Granger-causes broad money supply in all G7 countries that are included in their study. For the US, they use a sample that ends in 1992:4 and a quarterly broad money stock measure from the IMF Statistics for the U.S. economy, which differs somewhat from M2 and M3 definitions of the U.S. Federal Reserve. We instead use M3 broad money supply as reported in the H.8 Release of Federal Reserve and the more inclusive overall bank credit of depository institutions instead of 'total bank credit of US commercial banks' used by them, ${ }^{9}$ and our sample spans from 1960 to 2005. We otherwise use the exact replica of their model, following the same procedure to estimate the same set of variables. ${ }^{10}$ We find that the cointegration relationship between total bank credit and the broad money supply is not stable for the extended period in our sample. Reestimating the VECM for different subperiods, we find that this is because the statistical 
relationship between M3 and overall bank credit of depository institutions weakens after 1995 when the cointegration relationship disappears.

The second set of evidence showing a weakened statistical relationship between M3 broad money supply and total bank credit of depository institutions comes from ordinary least squares (OLS) estimates we have conducted ourselves for three subperiods, 1959-1979, the period of regulation; 1980-1994, the first wave of deregulation, and, 1995-2005, the second wave of deregulation. The break points, though seemingly straightforward in retrospect, are also statistically verified by Chow breakpoint and Chow forecast tests. ${ }^{11} \mathrm{We}$ work with first differences for which unit root tests show both variables as stationary for the period as a whole, though not for all subperiods (Table 4). ${ }^{12}$ When AR and MA estimators are included autocorrelation problems disappear and the error-terms do not show any sign of heteroskedasticity (Table 5).

Table 4: ADF Tests

\begin{tabular}{|c|c|c|c|c|c|c|}
\hline $\begin{array}{l}\text { Sample: } \\
\text { 1959:1-2005:2 }\end{array}$ & ADF Test Static & 1 percent & 5 percent & 10 percent & $\begin{array}{l}\text { Constant } \\
\text { and/or } \\
\text { time } \\
\text { trend }\end{array}$ & $\begin{array}{l}\text { Lag } \\
\text { length }\end{array}$ \\
\hline $\mathrm{d}(\ln \mathrm{M} 3)$ & -3.524 & -3.467 & -2.877 & -2.575 & $\mathrm{C}$ & 2 \\
\hline d(lnDEPTBANKCREDIT) & -2.622 & -3.468 & -2.877 & -2.575 & $\mathrm{C}$ & 7 \\
\hline $\begin{array}{l}\text { Sample: } \\
\text { 1959:1-1979:4 }\end{array}$ & ADF Test Static & 1 percent & 5 percent & 10 percent & $\begin{array}{l}\text { Constant } \\
\text { and/or } \\
\text { time } \\
\text { trend }\end{array}$ & $\begin{array}{l}\text { Lag } \\
\text { length }\end{array}$ \\
\hline $\mathrm{d}(\ln \mathrm{M} 3)$ & -3.996 & -3.513 & -2.897 & -2.585 & $\mathrm{C}$ & 2 \\
\hline d(lnDEPTBANKCREDIT) & -3.438 & -3.516 & -2.899 & -2.586 & $\mathrm{C}$ & 5 \\
\hline $\begin{array}{l}\text { Sample: } \\
\text { 1980:1-1994:4 }\end{array}$ & ADF Test Static & 1 percent & 5 percent & 10 percent & $\begin{array}{l}\text { Constant } \\
\text { and/or } \\
\text { time } \\
\text { trend }\end{array}$ & $\begin{array}{l}\text { Lag } \\
\text { length }\end{array}$ \\
\hline $\mathrm{d}(\ln \mathrm{M} 3)$ & -3.667 & -4.116 & -3.484 & -3.17 & $\mathrm{C}, \mathrm{t}$ & 1 \\
\hline d(lnDEPTBANKCREDIT) & -1.211 & -2.603 & -1.946 & -1.618 & None & 4 \\
\hline $\begin{array}{l}\text { Sample: } \\
\text { 1995-2005:2 }\end{array}$ & ADF Test Static & 1 percent & 5 percent & 10 percent & $\begin{array}{l}\text { Constant } \\
\text { and/or } \\
\text { time } \\
\text { trend }\end{array}$ & $\begin{array}{l}\text { Lag } \\
\text { length }\end{array}$ \\
\hline $\mathrm{d}(\ln \mathrm{M} 3)$ & -2.528 & -3.593 & -2.932 & -2.603 & $\mathrm{C}$ & 2 \\
\hline d(lnDEPTBANKCREDIT) & -3.139 & -4.189 & -3.518 & -3.189 & $\mathrm{C}, \mathrm{t}$ & 6 \\
\hline
\end{tabular}


Table 5: Diagnostic Tests

\begin{tabular}{|c|c|c|c|c|c|c|c|c|}
\hline \multirow[b]{2}{*}{ Breusch-Godfrey } & \multicolumn{2}{|c|}{$1959: 4-2005: 2$} & \multicolumn{2}{|c|}{ 1959:4-1979:4 } & \multicolumn{2}{|c|}{ 1980:1-1994:4 } & \multicolumn{2}{|c|}{ 1995:1-2005:2 } \\
\hline & & & & & & & & \\
\hline $\begin{array}{l}\text { Serial Correlation } \\
\text { LM Test: }\end{array}$ & & Probability & & Probability & & Probability & & Probability \\
\hline F-statistic & 0.585 & 0.557 & 1.112 & 0.334 & 0.555 & 0.577 & N/A & N/A \\
\hline Obs*R-squared & 1.223 & 0.542 & 2.444 & 0.294 & 1.303 & 0.521 & N/A & N/A \\
\hline $\begin{array}{l}\text { White } \\
\text { Heteroskedasticity } \\
\text { Test: }\end{array}$ & & Probability & & Probability & & Probability & & Probability \\
\hline F-statistic & 0.926 & 0.465 & 0.644 & 0.666 & 1.63 & 0.168 & N/A & N/A \\
\hline Obs*R-squared & 4.664 & 0.458 & 3.334 & 0.648 & 7.861 & 0.164 & N/A & N/A \\
\hline
\end{tabular}

As expecteded, our estimates differ considerably between different subperiods. A strong statistical relationship between the overall bank credit and the broad money supply is evident for the first two subperiods, but it breaks down for the last subperiod, when the coefficient of overall bank credit turns negative and insignificant, while the adjusted $\mathrm{R}^{2}$ becomes nil (Table 6 ). For every one percent increase in the overall bank credit the broad money supply rose 0.5 percent in the first subperiod, 0.22 percent in the second subperiod and was statistically insignificant in the third. ${ }^{13}$ The OLS results confirm our initial finding that the statistical relationship between broad money supply and overall bank credit of depository institutions has weakened, if not disappeared, after 1995.

Table 6. OLS Estimations

\begin{tabular}{llllll}
\hline $\mathrm{D}(\ln (\mathrm{M} 3))$ & $\mathrm{d}(\ln (\mathrm{DEPTBANKCREDIT}))$ & $\mathrm{C}$ & $\mathrm{AR}(1)$ & $\mathrm{MA}(1)$ & Adj. $^{2}$ \\
\hline $1959: 32005: 2$ & 0.262 & 0.011 & 0.885 & -0.475 & 0.568 \\
& {$[4.854]$} & {$[4.458]$} & {$[17.881]$} & {$[-5.114]$} & \\
$1959: 31979: 4$ & 0.499 & 0.005 & 0.602 & & 0.674 \\
& {$[6.181]$} & {$[1.706]$} & {$[6.208]$} & & \\
$1980: 11994: 4$ & 0.22 & -0.097 & 0.996 & -0.969 & 0.771 \\
& {$[3.266]$} & {$[-0.328]$} & {$[93.044]$} & {$[-58.544]$} & \\
$1995: 1-2005: 2$ & -0.156 & 0.022 & & & -0.086 \\
& {$[-0.898]$} & {$[4.34]$} & & & \\
\hline
\end{tabular}

Notes: 1. t-values are in parenthesis.

2. DEPTBANKCREDIT is overall bank credit of depository institutions.

\section{Discussion of Results}

Our findings appear to pose a puzzle. When bank credit increases on the asset side of depository institutions' balance sheet, there has to be a corresponding increase on the liability side as well; and, if new deposits are rising, broad money (the sum of deposits) must also have risen. The theory of endogenous supply of money is really an argument about the direction of 
causation between total bank credit and broad money aggregates, but otherwise it takes the connection between them for granted (Figure 2). But, the trouble is that the econometric evidence we uncover shows that the link between total bank credit and the broad money supply could no longer be taken for granted.

Figure 2. The Relationship Between Total Bank Credit and Broad Money Supply

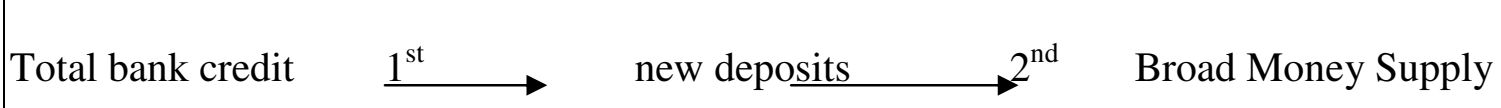

The explanation of our puzzle can rest on two sources. It can be the case that, in the period after 1995, (i) the expansion of bank credit did not result in a commensurate increase of bank deposits, or, that (ii) under changing conditions our definition of broad money supply ceased to reflect accurately the total sum of financial vehicles that were being used as "money" in the economy. In other words, the problem can lie in the first or the second (or both) leg(s) of the relationship in Figure 2. A cursory look at bank credit, M3 and total deposits of depository institutions - all normalized by GDP - shows that they all move together up until 1995, but began to diverge afterwards, especially, during the period 1995 to 2000 (Figure 3). Total deposits stay flat while both bank credit and M3 continue to increase, but at a quite varied pace. A good part of bank credit expansion, it appears, was not reflected in total deposits. Nor does it seem like the M3 and total bank deposits were highly correlated. 
Figure 3. Bank Credit, Deposits, and M3

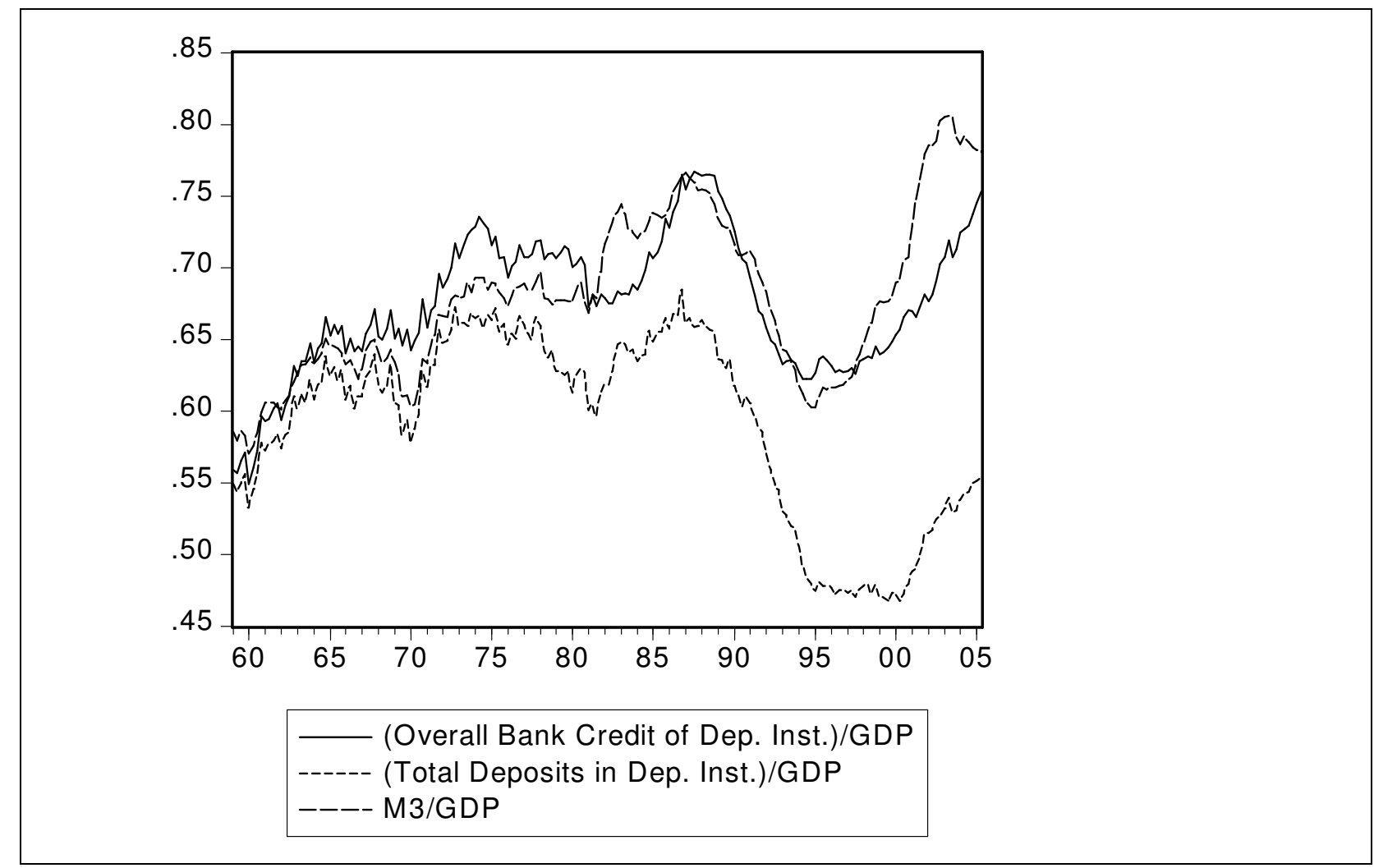

Source: U.S. Federal Reserve System H.8 Release and L.109, L.114 and L.115 tables of Flow of Funds Accounts.

We conjecture that the explanation has to do with three interrelated trends that gained momentum after the mid 1990s: (i) rising importance of non-deposit liabilities of banks, (ii) easing of reserve requirements, and (iii) increased ability to securitize assets. The main result of these developments was to free banks from traditional constraints such as required reserves and deposits as well as those imposed by their capital base in extending credit. The growing importance of nonbank intermediation was the telltale sign of these changes. A goo deal has already been written about these changes and the growing importance of nonbank intermediation which has been their telltale sign, so we can be brief.

As mentioned earlier, facing increased competition from higher yielding money market mutual funds, depository institutions experienced falling core deposits and were forced to engage increasingly in liability management in the era of financial liberalization. With the emergence of certificates of deposits, increased access to the federal funds markets and use of credit market instruments liability management had acquired a level of importance unimaginable just a few years before. Individual banks could now actively pursue profitable opportunities and smooth out maturity mismatches in their balance sheets in relative independence from deposits. Whatever constraint deposits might still have imposed on bank credit was further relaxed by the drastic easing of reserve requirements by the mid-1990s. In the second wave of deregulation, ${ }^{14}$ the Fed abolished reserve requirements for time deposit accounts and reduced them for checkable deposits in 1992, and, later in 1994 retail sweep accounts were introduced, following of which required reserves for all intents and purposes ceased to be an issue (Bennett and Peristani, 2002). 
Now free to move funds from reserve accounts to lending instruments with ease, depository institutions could manage their assets with a level of discretion that was unprecedented. Finally, with asset securitization, eased by the shift of lending towards loans collateralized by real estate, new layers of intermediation emerged, expanded and multiplied, unreflected in banks' balance sheets such that constraints imposed by their capital base could now be sidestepped. Extension of bank lending as a result increasingly resulted in the creation of new debt instruments by other financial institutions, and thus the connection between bank lending and deposits was weakened just as the nondepository component of M3 - money market mutual fund shares - soared (Samolyk, 2004; Kregel, 2007). The rapid increase of MMMFs ${ }^{15}$ in M3 after 1995, reaching almost 30 percent by 2001, gives an idea about the magnitude nonbank financial intermediation has reached (Figure 4).

Figure 4. Nonbank Deposits in M3

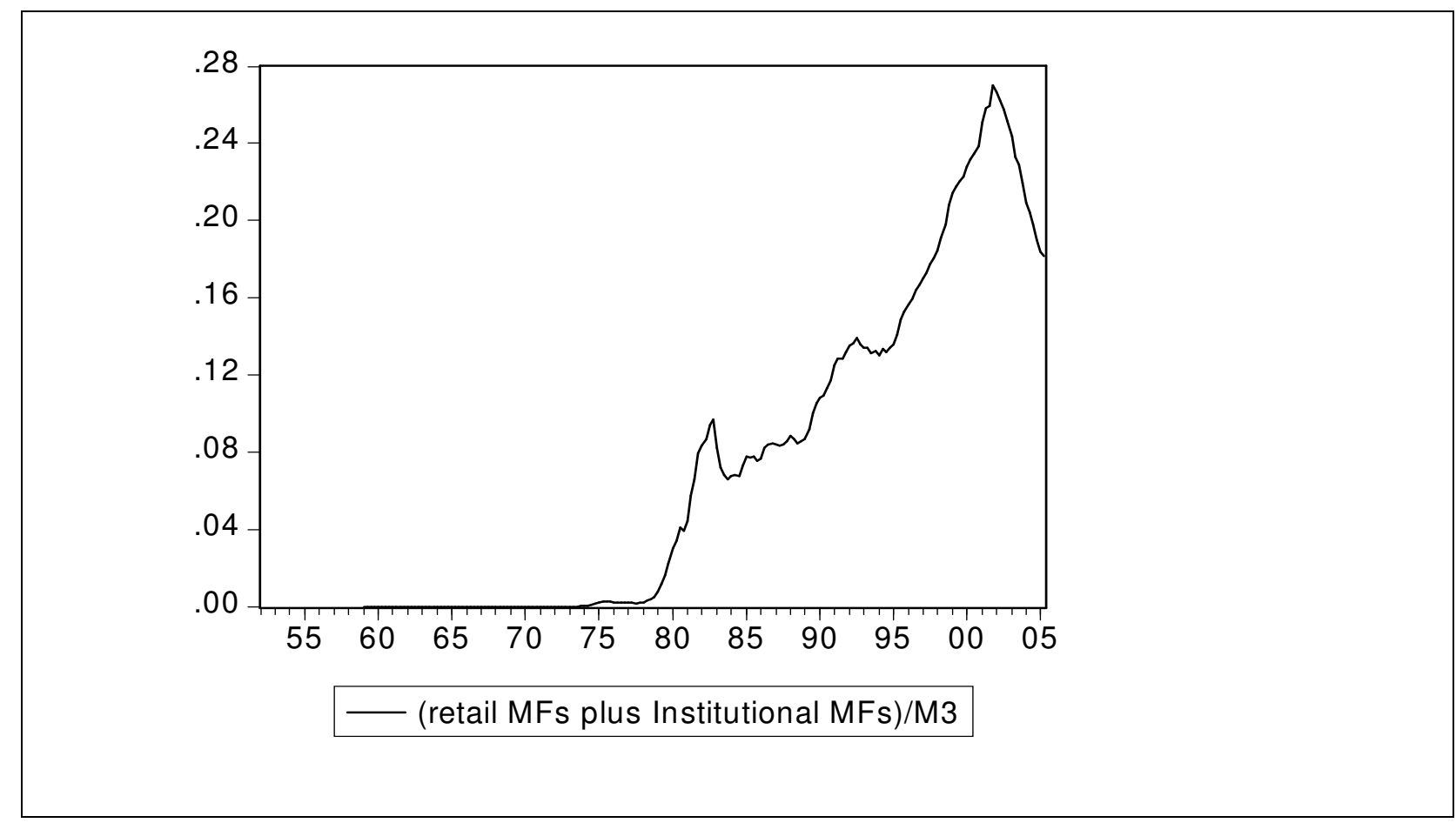

Source: Federal Reserve Bank of St. Louis, FRED 2 Data Release.

All this implies that the link between bank credit and broad money has acquired a new form that goes well beyond what is represented by the simple set of unidirectional arrows in Figure 2. Though the old loan-deposit relation might still hold, it is now overlaid with a new set of relations. In Figure 5, lines starting from banks' nondeposit liabilities on one side (3a) and reduced required reserves on the other $(3 \mathrm{~b})$ point to bank credit, emphasizing the increased discretion with which banks now extended credit. Banks initiate and process borrowing instruments such as mortgages, but many of these assets no longer stay in their balance sheets as they are passed on to other institutions through asset securitization. In other words, financial intermediation spills over (4) to nondepository institutions who issue new debt instruments against these assets, leading to an eventual increase in the relative magnitude of nonbank deposits (5) within M3. The dotted lines are for the opaque and circuitous layers involved in this process 
as an increasingly complex set of financial instruments are issued by the nondepository financial institutions that are difficult to track.

Summing up then in connection with the question we started out this section with, the first leg of the relation in Figure 2, seems not hold because in extending credit banks have increasingly been relying on nondeposit liabilities, reduced reserve requirements and asset securitization; and, the second leg does no longer hold because the relative importance of nondepository institutions' liabilities in broad money has risen due to the increasing commodification of credit.

Figure 5. New Relationship Between Total Bank Credit and Broad Money Supply

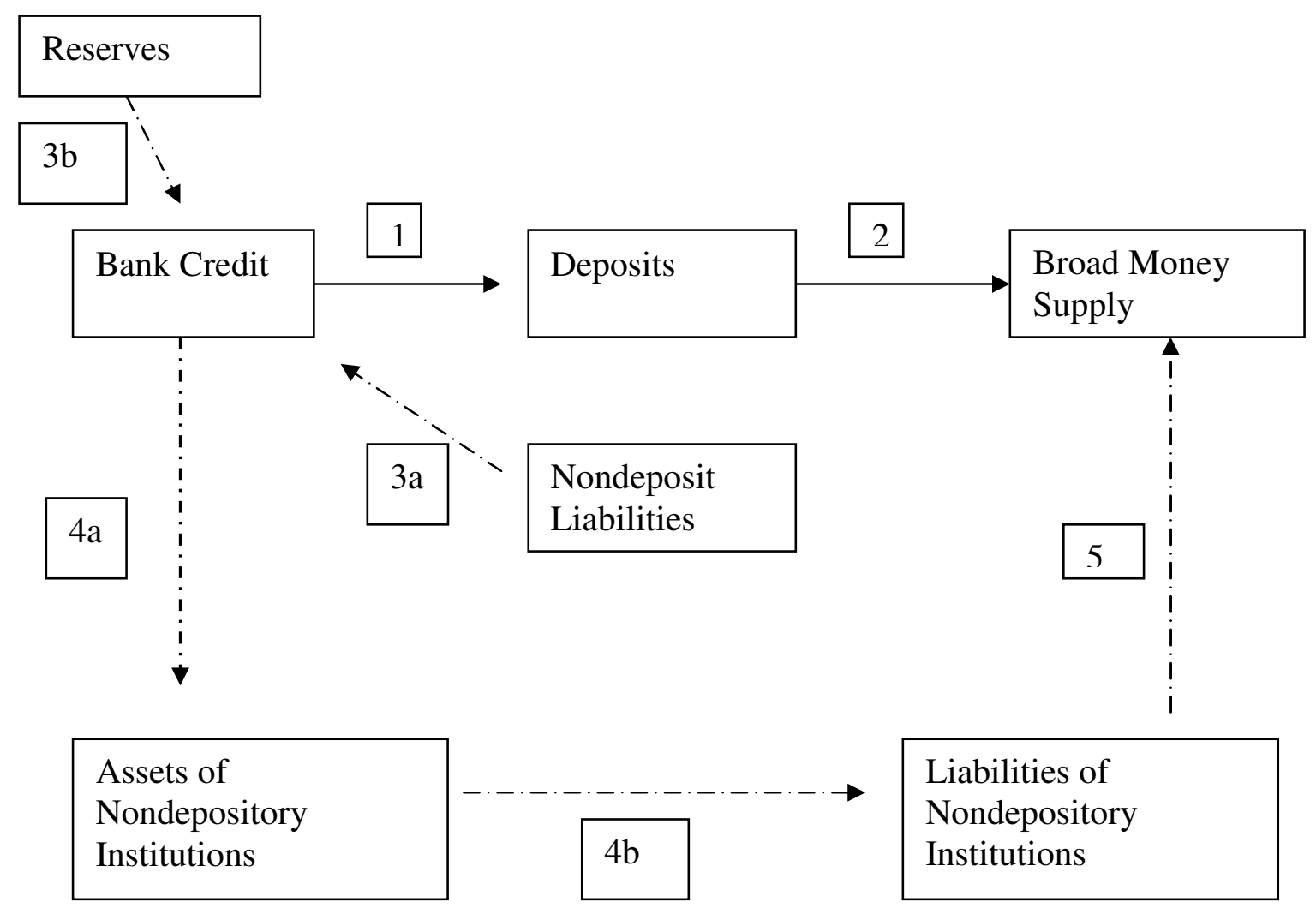

\section{Conclusion}

In this paper we have shown that the link between bank credit and broad money has substantially weakened after the mid-1990s because of the changing nature of the credit creation process where nonbanks' role in financial intermediation has greatly increased. On the one hand, this can be seen an indication of what is fundamentally a technical problem emanating from the difficulty of coming up with the right measure of broad money in this period. If this were the case, some measure of broad money other than M3 could potentially give the kind of positive 
results we searched for and failed to find. Clearly, the reason why the second leg of the relation in Figure 2 does no longer hold is because of the growing importance of nondepository institutions' liabilities in M3. Under the changing conditions of the 1990s broad money appears to have become broader than banks' total deposits, and thus one wonders if bank credit is linked to a narrower measure of broad money that excludes nonbank deposits. That, we find, does not seem to be the case. It is, of course, possible that other researchers might find that right measure of broad money we could not, but we think that the reason for our failure to do so is because the first leg of the relation in Figure 2 is also broken. When we turn our attention here, it is the active role banks have come to play in credit creation that stands out. Not only banks have acquired almost total independence from required reserves and core deposits, but also the kind of asset maneuverability securitization enabled helped them circumvent the constraint posed by their capital base. When they lacked enough capital to put loans on their balance sheet, they went on to create off balance sheet vehicles to carry them anyway and the credit expansion multiplied. All this contrasts starkly with a situation where banks respond relatively passively to credit demand driven by the "state of trade." Whether bank credit might have been driven by asset price expectations that became self-fulfilling in this new era is an intriguing idea that is worthwhile to pursue. It might help explain why the connection between the "state of trade" and bank loans might also have become tenuous, as Caporale and Howells (2001) report, and is consistent with the anecdotal evidence on loan pushing by banks in the subprime debacle. 


\section{Endnotes:}

${ }^{1}$ During the same time, non-GDP transactions were also being discussed in terms of their impact on the transactions demand for money (Palley, 1995; Pollin and Schaberg; 1998, Howells and Hussein, 1997).

${ }^{2}$ Here we use bank loans not elsewhere classified from the flow of funds accounts that approximately corresponds to the sum of commercial and industrial loans plus "other loans and leases" reported under H8. Assets and Liabilities of Commercial Banks in FED's data release. But, unlike the latter, it is quarterly and includes not only commercial banks but also Savings Institutions and Credit Unions.

${ }^{3}$ Following a procedure used by Weiskopf (1979) and Pollin (1991), we compute growth rates by taking the log differences from one cycle midpoint to the next, averaged out for the number of years in that cycle, after ascribing the mean values of each variable for a given cycle to the midpoint of that cycle.

${ }^{4}$ These include "service charges on deposits, income from fiduciary activities trading income, merchant credit, card fees, annual cardholder fees, fees from servicing mortgages, and income from loans that have been securitized" (Nelson and Owen, 1997; 472).

${ }^{5}$ On the changing role of bank credit, see also: Rogers and Sinkey, 1999; Saidenberg and Strahan, 1999; and Samolyk (2004); and Bradley and Shibut, 2006.

${ }^{6}$ See Emmons, Lskavyan, and Yeager, (2005: 13); Basset and Zakrajsek (2003: 482); Cornford, (2005) on the negative impact the 1988 Basel Capital Accord have had on traditional forms of bank lending such as commercial and industrial loans.

${ }^{7} \mathrm{M} 1, \mathrm{M} 2$, and MZM have variously been tried as narrow money measures in the last two decades to no avail.

${ }^{8}$ The Fed stopped releasing M3 in March 2006 after successive redefinitions of both M2 and M3. Our discussion in the next section gives some idea about the difficulties involved in defining an adequate measure of broad money under the changing conditions and instruments of liquidity.

${ }^{9}$ The overall bank credit of depository institutions includes commercial banks, savings institutions and credit unions as given in L.109, L.114 and L.115 tables of Flow of Funds Accounts of Federal Reserve, respectively.

${ }^{10}$ See Appendix I for the technical details of our findings.

${ }^{11}$ Different stability tests signaled different break points, but the plot of residuals indicated breaks in 1970, 1980, 1995, and 2000. When we alternatively used business cycles as subperiods, our results were broadly similar.

12 To deal with this problem, we reran our estimations after applying the Hodrick-Prescott Filter. Chow breakpoint and Chow forecast tests again revealed the existence of structural breaks for the first quarters of 1980 and 1995, and the OLS estimates of coefficients, and their levels of statistical significance, were not much different from our previous estimates.

${ }^{13}$ In our estimates using Hodrick-Prescott filtered variables, these same coefficients were 0.6 and 0.17 , respectively, for the first and second subperiods, and, again, negative and insignificant for the third. 
${ }^{14}$ Depository Institutions Deregulation and Monetary Control Act (1980) - which abolished interest rate ceilings for most of the deposit accounts and introduced negotiable orders of withdrawal (NOWs) accounts - and Garn-St. Germain Depository Institutions Act (1982) that ushered in the money market deposit accounts was the first wave.

${ }^{15}$ Retail funds are included under M2 and institutional funds under M3, while in flow of funds accounts the two are bunched together. 


\section{References}

Arestis, P. and Mariscal, I. B. F. 1995. The endogenous money stock: empirical observations from the United Kingdom, Journal of Post Keynesian Economics, vol. 17 no. 4, 545-59

Basset, W. F. and Zakrajsek, E. 2000. Profits and balance sheet developments at U.S. commercial banks in 1999, Federal Reserve Bulletin, March, 367-95

Boyd, J. H. and Gertler, M. 1995. Are banks dead? Or are the reports greatly exaggerated?, NBER, Working Paper No. 5045

Bradley, C. M. and Shibut, L. 2006. The liability structure of FDIC-insured institutions: changes and implications, FDIC Banking Review, vol. 18, no. 2, 1-37

Caporale, G. and Howells, P. 2001. Money, Credit and Spending: Drawing Causal Inferences, Scottish Journal of Economics, vol. 48, no. 5, 547-57.

Cornford, A. 2005. Basel II: The revised framework of June 2004. UNCTAD, Discussion Paper No. 178

Dow, S. 2007. Endogenous Money: Structuralist, in Arestis, P. and Sawyer, M. (eds), A Handbook of Alternative Monetary Economics, Northampton, MA, Edward Elgar.

Edwards, F. R. and Mishkin, F. S. 1995. The decline of traditional banking: Implications for financial stability and regulatory policy. Federal Reserve Bank of New York Economic Policy Review, vol. 1, no. 2, 27-45

Emmons, W. R., Lskavyan, V. and Yeager, T. J. 2005. Basel II will trickle down to community bankers, consumers. Federal Reserve Bank of St. Louis The Regional Economist, April, $12-13$

Fontana, G. 2003. Post Keynesian approaches to endogeneous money: a time framework explanation, Review of Political Economy, vol. 15, no. 3, 291-314

Hewitson, G. 1997. The Post Keynesian 'demand for credit' model, Australian Economic Papers, vol. 36 , no. $2,127-143$

Howells, P. 2007. The Endogeneity of Money: The Empirical Evidence, in Arestis, P. and Sawyer, M. (eds), A Handbook of Alternative Monetary Economics, Northampton, MA, Edward Elgar.

Howells, P. and Hussein, K. 1997. The Demand for Money: Total Transactions as the Scale Variable, Economic Letters, vol. 55, no. 3, 371-7.

Howells, P. and Hussein, K. A. 1998. The endogeneity of money: evidence from G7, Scottish Journal of Political Economy, vol. 45, no. 3, 329-40 
Howells, P. \& Hussein, K. 1999. The Demand for Bank Loans and the "State of Trade," Journal of Post Keynesian Economics, vol. 21, no. 3, 441-54.

Kregel, J. 2007. The Natural Instability of Financial Markets, The Levy Economics Institute, Working Paper No. 523.

Lavoie, M. 2007. Endogenous Money: Accomodationist, in Arestis, P. and Sawyer, M. (eds), A Handbook of Alternative Monetary Economics, Northampton, MA, Edward Elgar.

Moore, B. and Threadgold, A. 1985. Corporate Bank Borrowing in the UK, 1965-81, Economica, vol. 54, 65-78.

Moore, B. 1988. Horizontalists and Verticalists, Cambridge, Cambridge University Press.

Moore, B. 1989. The endogeneity of credit money, Review of Political Economy, vol. 1, no. 1, 65-93

Nelson, W. R. and Owen, A. L. 1997. Profits and balance sheet developments at U.S. commercial banks in 1996. Federal Reserve Bulletin, June, 465-89

Palley, T. I. 1994. Competing views of the money supply process: theory and evidence, Metroeconomica, vol. 45, no.1, 67-88

Palley, T. 1995. The Demand for Money and Non-GDP Transactions, Economic Letters, vol. 48, 145-54.

Pollin, R. 1991. Two theories of money supply endogeneity: some empirical evidence, Journal of Post Keynesian Economics, vol. 13, no.3, 366-96

Pollin, R. and Schaberg, M. 1998. Asset exchanges, financial market trading, and the M1 income velocity puzzle, Journal of Post Keynesian Economics, vol. 21, no. 1, 135-162

Rogers, K. and Sinkey Jr, J. F. 1999. An analysis of nontraditional activities at U.S. commercial banks, Review of Financial Economics, vol. 8, no. 1, 25-39

Saidenberg, M. R. and Strahan, P. E. 1999. Are banks still important for financing large business?, Federal Reserve Bank of New York Current Issues in Economics and Finance, vol. 5, no. 2, 1-6

Samolyk, K. 2004. The future of banking in America, FDIC Banking Review, vol. 16, no. 2, 2965

Weisskopf, T. E. 1979. Marxian crisis theory and the rate of profit in the postwar U.S. economy, Cambridge Journal of Economics, vol. 3, no. 4, 341-78 
Whitesell, W. and Collins, S. 1995. A minor redefinition of M2. Monetary Affairs Division, Board of Governors of the Federal Reserve, Finance and Economic Discussion Series No. 96-7.

\section{Appendix I}

In matrix notation, the VECM in Howells and Hussein (1998) takes the form:

$$
\Delta X_{\mathrm{t}}=\alpha \beta^{\prime} X_{\mathrm{t}-1}+\Gamma \Delta X_{\mathrm{t}-1}+\mu+\varepsilon_{\mathrm{t}}
$$

The table below summarizes their results for the US for the period, 1957:1 to 1992:4.

\begin{tabular}{|c|c|c|c|c|c|}
\hline Dep. Variable & $\alpha$ & B & $\begin{array}{l}\sum \Delta \log \\
\text { (broadmoney) } 1\end{array}$ & $\begin{array}{l}\sum \Delta \log \\
(\text { banklending) }\end{array}$ & $\begin{array}{l}\text { Number } \\
\text { of lags }\end{array}$ \\
\hline $\log (b$ & -0.24 & 0.86 & -0.59 & 0.5 & 6 \\
\hline Log(banklending) & -0.19 & 1.16 & 0.57 & -0.64 & 6 \\
\hline
\end{tabular}

${ }^{\mathrm{T}}$ Howells and Hussein, 1998, p. 336 only summed the significant lagged dynamic terms.

Working with the same natural log form of the same variables in Howells and Hussein (1998), the VECM model we estimated is the exact replica of theirs.

$$
\Delta X_{\mathrm{t}}=\alpha \beta^{\prime} X_{\mathrm{t}-1}+\Gamma \Delta X_{\mathrm{t}-1}+\mu+\varepsilon_{\mathrm{t}},
$$

We first estimated the cointegrating relationship between these two variables by using the optimal length of lags given by AIC and SC statistics for the sample period, 1960:2 and 2005:2. The AIC test gave an optimal leg of 5 whereas SC gave it as 4 . We then ran our estimations using the Johansenn method with Trace Test by E-Views with 4 lags. The cointegration component of our results was similar to Howells and Hussein's even though the vector autoregression component, in the second row was different:

Our VECM for Extended Sample

\begin{tabular}{llllll}
\hline Dep. Variable & $\alpha$ & $\mathrm{B}$ & $\begin{array}{l}\sum \Delta \log \\
(\mathrm{M} 3)^{1}\end{array}$ & $\begin{array}{l}\sum \Delta \log \\
\text { (depositoryins.lending) }^{1}\end{array}$ & $\begin{array}{l}\text { Number } \\
\text { of lags }\end{array}$ \\
\hline $\log$ (M3) & -0.011 & 1.029 & 0.627 & 0.137 & 4 \\
$\begin{array}{l}\text { Log } \\
\text { (depositoryins.lending) }\end{array}$ & 0.057 & 0.97 & -0.342 & 0.951 & 4 \\
\hline
\end{tabular}

${ }^{1}$ The sum of significant variables are reported for the vector autoregression component.

Data Source: U.S. Federal Reserve System H.8 Release and L.109, L.114 and L.115 tables of Flow of Funds Accounts. 
While it still can be argued that both the long and short-run components of the VECM we report are in accordance with Howells and Hussein's results, the cointegration relationship was not stable when the error term of the relationship was checked (Fig 3.1), and the likelihood Ratio test in J-Multi showed no cointegrating relationship at all. We also tried dropping the cointegration component and estimated an unrestricted vector autoregressive (VAR) model. However, the error terms of this new VAR model did not show stability either.

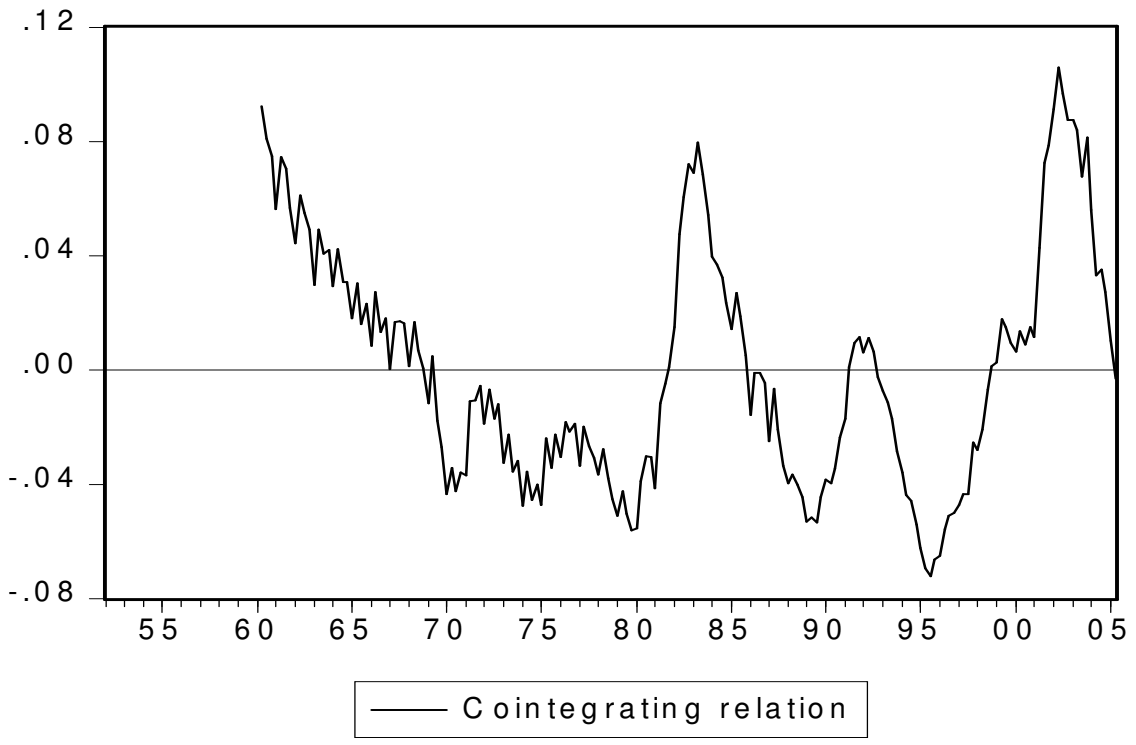

